\title{
Leaf application of silicon in young cacao plants subjected to water deficit
}

\author{
Leonardo Valandro Zanetti(1), Camilla Rozindo Dias Milanez ${ }^{(1)}$, Vinícius Novo Gama(1), \\ Marco Antonio Galeas Aguilar( ${ }^{(2)}$, Carlos Alberto Spaggiari Souza ${ }^{(2)}$, Eliemar Campostrini( ${ }^{(3)}$, \\ Tiago Massi Ferraz ${ }^{(4)}$ and Fábio Afonso Mazzei Moura de Assis Figueiredo(4)
}

\begin{abstract}
(1)Universidade Federal do Espírito Santo, Centro de Ciências Humanas e Naturais, Departamento de Ciências Biológicas, Avenida Fernando Ferrari, no 514, Prédio Bárbara Weinberg, Campus Goiabeiras, CEP 29075-910 Vitória, ES, Brazil. E-mail: valandroleo@gmail.com, camilla.milanez@gmail.com, vinicius_novo@hotmail.com ${ }^{(2)}$ Centro de Pesquisas do Cacau, Estação Experimental Filogônio Peixoto, Caixa Postal 102, CEP 29901-970 Linhares, ES, Brazil. E-mail: magaguilar@uol.com.br, spaggiari.ceplac@gmail.com (3)Universidade Estadual do Norte Fluminense Darcy Ribeiro, Centro de Ciências e Tecnologias Agropecuárias, Setor de Fisiologia Vegetal, Avenida Alberto Lamego, no 2.000, Parque Califórnia, CEP 28013-602 Campos dos Goytacazes, RJ, Brazil. E-mail: campostenator@gmail.com (4)Universidade Estadual do Maranhão, Centro de Estudos Superiores de Imperatriz, Departamento de Química e Biologia, Rua Godofredo Viana, no 1300, Centro, CEP 65900-000 Imperatriz, MA, Brazil. E-mail: ferraztm@gmail.com, figueiredo.uema@gmail.com
\end{abstract}

Abstract - The objective of this work was to evaluate the physiological and anatomical traits of plants of a cacao (Theobroma cacao) clone in response to water deficit after leaf application of silicon. A randomized complete block design was used, with four replicates, in a $2 \times 3$ factorial arrangement of two water regimes (irrigated or nonirrigated) and three silicon concentrations $\left(0.0,1.5\right.$, and $\left.3.0 \mathrm{mg} \mathrm{mL}^{-1}\right)$ applied in wettable $\mathrm{SiO}_{2}$ powder. The plants were evaluated 20 days after the irrigation regimes were applied. The use of $\mathrm{SiO}_{2}$ increased the stability of cell membranes and the photochemical efficiency of the plants under water deficit. The $1.5 \mathrm{mg} \mathrm{mL}^{-1}$ concentration of $\mathrm{SiO}_{2}$ increased photosynthetic rate, water use efficiency, and carboxylation efficiency, besides mitigating the effect of oxidative stress. Stomatal density was reduced in nonirrigated plants under the highest concentration of $\mathrm{Si}$. The $1.5 \mathrm{mg} \mathrm{mL}^{-1}$ concentration of $\mathrm{Si}$ is considered optimal for the photosynthetic metabolism of young cacao plants under soil water limitation.

Index terms: Theobroma cacao, anatomy, antioxidant enzymes, drought, photochemistry, $\mathrm{SiO}_{2}$.

\section{Aplicação foliar de silício em plantas jovens de cacau submetidas à deficiência hídrica}

\begin{abstract}
Resumo - O objetivo deste trabalho foi avaliar as características fisiológicas e anatômicas de plantas de um clone de cacau (Theobroma cacao) em resposta ao deficit hídrico após a aplicação foliar de silício. Utilizou-se o delineamento de blocos ao acaso, com quatro repetições, em arranjo fatorial $2 \times 3$, com dois regimes hídricos (irrigado e não irrigado) e três concentrações de silício $\left(0,1,5\right.$ e 3,0 $\left.\mathrm{mg} \mathrm{mL}^{-1}\right)$ aplicadas como pó molhável de $\mathrm{SiO}_{2}$. As plantas foram avaliadas 20 dias após a aplicação dos regimes de irrigação. O uso de $\mathrm{SiO}_{2}$ aumentou a estabilidade das membranas celulares e a eficiência fotoquímica das plantas sob deficit hídrico. A concentração

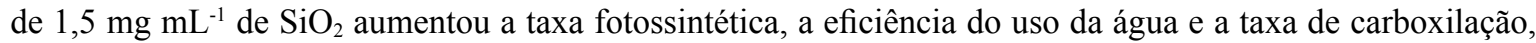
além de ter mitigado o efeito do estresse oxidativo. A densidade estomática foi reduzida em plantas não irrigadas sob a maior concentração de Si. A concentração de $1,5 \mathrm{mg} \mathrm{mL}^{-1}$ de Si é considerada ótima para o metabolismo fotossintético de plantas jovens de cacau sob limitação de água no solo.
\end{abstract}

Termos para indexação: Theobroma cacao, anatomia, enzimas antioxidantes, seca, fotoquímica, $\mathrm{SiO}_{2}$.

\section{Introduction}

The current climate change models predict that limitations in water availability will increase in frequency and in severity in several regions of the world (Stocker et al., 2013). Therefore, there is an increasingly urgent need to reduce the impact of water restrictions on plant metabolism, particularly related to the morphophysiological response mechanisms of plants in drought conditions.

The cacao (Theobroma cacao L.) plant is a tree species of the Malvaceae family (Souza \& Lorenzi, 2005). The seeds are used for the production of chocolate and in the pharmaceutical and cosmetic industries. The cacao plant grows in the tropical climates of Brazil, mainly in the Northeast Region 
and in other areas with low rainfall. However, water deficit still impairs crop yield of adult cacao plants and negatively affects the growth of cacao seedlings (Almeida \& Valle, 2010). Furthermore, physiological responses of cacao are affected when the soil water content is below $60-70 \%$ of the maximum available soil water capacity (Alvim, 1960). In cacao, the leaf carbon export rate is sharply reduced with the decline of water potential between -0.8 and $-2.0 \mathrm{MPa}$, and this reduction is strictly associated with $\mathrm{CO}_{2}$ assimilation $(A)$ and export capacity, which is strongly reduced when $A$ approaches zero (Almeida \& Valle, 2010).

Under drought conditions, plant biomass decreases due to the decreased net photosynthetic rate because of a reduced stomatal conductance; consequently, chlorophyll concentration is also reduced. The decrease in the concentration of photosynthetic pigments causes impairments in photochemical activity. Moreover, the water deficit may also cause an imbalance in the antioxidant defense, which can induce oxidative stress on proteins, membrane lipids, and other cellular components (Reddy et al., 2004).

In the quest for technologies to mitigate the effects of drought on plants, fertilization with silicon ( $\mathrm{Si}$ ) has shown promise. The addition of Si can increase water use efficiency by reducing leaf transpiration and water flow rates in the xylem vessels (Gao et al., 2006), contributing to better photosynthetic rates (Shen et al., 2010). These improvements caused by Si deposition are attributed to this element in the cell wall, more specifically in the outer wall (Epstein, 1999), where it gives resistance and hardness (Ma \& Yamaji, 2006), resulting in more erect leaves, besides improving light interception and favoring photosynthesis. Another positive effect of the application of Si is its ability to mitigate the damage caused by oxidative stress on the plant tissues under drought conditions (Shen et al., 2010).

The objective of this work was to evaluate the physiological and anatomical traits of plants of a cacao (Theobroma cacao) clone in response to water deficit after leaf application of silicon.

\section{Materials and Methods}

The experiments were conducted at the Botany Department of Universidade Federal do Espírito Santo, located in the municipality of Vitoria, in the state of
Espírito Santo, Brazil $\left(20^{\circ} 18^{\prime} 52^{\prime \prime} \mathrm{S}, 40^{\circ} 19^{\prime} 06^{\prime \prime} \mathrm{W}\right)$, from April 2012 to November 2013, in a greenhouse with $50 \%$ photosynthetically active radiation intercepted on the site. The average relative humidity and temperature were $80 \%$ and $28^{\circ} \mathrm{C}$, respectively. The experimental design was a randomized complete block, with four replicates, in a $2 \times 3$ factorial arrangement of two water regimes (irrigated and nonirrigated) and three Si concentrations $\left(0.0,1.5\right.$, and $\left.3.0 \mathrm{mg} \mathrm{mL}^{-1}\right)$ applied to the leaves, resulting in a total of 24 plots with ten plants in each plot.

The experiments used clonal seedlings obtained from cuttings of the PH-16 cacao clone, with eight months of age and average height of $60 \mathrm{~cm}$. The plants were cultivated in 8.0-L polyethylene pots containing sieved and mixed soil of a clayey-sandy loam-type substrate with $54 \mathrm{~g} \mathrm{dm}^{-3}$ organic matter, $\mathrm{pH}\left(\mathrm{CaCl}_{2}\right)$ 6.1, containing the following atomic concentrations: $16 \mathrm{mmol}_{\mathrm{c}} \mathrm{dm}^{-3} \mathrm{H}+\mathrm{Al} ; 36 \mathrm{mmol} \mathrm{dm}^{-3} \mathrm{Ca} ; 22 \mathrm{mmol} \mathrm{dm}^{-3}$ $\mathrm{Mg} ; 0.0 \mathrm{mmol} \mathrm{dm}^{-3} \mathrm{Al} ; 450 \mathrm{mg} \mathrm{dm}^{-3} \mathrm{~K} ; 192 \mathrm{mg} \mathrm{dm}^{-3}$ $\mathrm{P}$ (Mehlich-1); and $12 \mathrm{mg} \mathrm{dm}^{-3} \mathrm{Si}$ (base saturation of 78.5\%). Silicon was applied between 8:00 and 9:00 AM (single dose), using a manual sprayer, on both leaf surfaces (approximately $25 \mathrm{~mL}$ per plant) at 15 days before applying the water stress treatment. The $\mathrm{Si}$ source was a wettable fertilizer powder containing $98 \% \mathrm{SiO}_{2}$ (Agri Sil, Agrobiológica - Soluções Naturais Ltda., Leme, SP, Brazil).

The water deficit treatment was obtained by cutting out irrigation for a 20-day period. In the irrigated treatment, the plants received the application of Si and were subjected to watering every two days, to maintain the maximum field capacity of the substrate. During the application of water to the soil of the control plants, as well as in all treatments, there was no wetting of the leaves.

All analyses were performed at the end of the experiment in fully expanded leaves of the second or third node from the apex of the orthotropic axis of three plants per block, resulting in 12 plants per treatment. Portions of the leaf samples were frozen in liquid nitrogen and stored in an ultra-freezer at $-80^{\circ} \mathrm{C}$ for later use in biochemical analyses, while the other portions were fixed in $70 \%$ ethanol for the anatomical analysis.

For the anatomical analysis, eight segments of the middle portions of each leaf blade were used, which were dehydrated in an ascending ethanol series and embedded in hydroxyethyl methacrylate (Historesin, 
Leica Biosystems Nussloch GmbH, Heidelberg, Germany), according to the manufacturer's recommendations. The blocks were cut transversely (10 $\mu \mathrm{m}$ thick) with a rotary microtome and were stained with toluidine blue (O'Brien et al., 1964). The following were measured: total thickness of blades, epidermis of both leaf surfaces, and palisade and spongy parenchymas. Using an instant adhesive, stomatal density (number per $\mathrm{mm}$ ) was also determined from the abaxial leaf surface using the technique of epidermal fingerprint on glass slides.

Histochemical tests were performed on crosssections of fresh and fixed leaves according to the methods described by Johansen (1940). For detection of mucilage, an aqueous solution of ruthenium red was used, in which a positive reaction was indicated by a pink color. For detection of starch, Lugol's reagent was used, and staining was considered positive when a dark-blue to black color was observed.

Observation and photographic documentation were performed using a Nikon Eclipse 50i photomicroscope and the Nikon NIS-Elements microscope imaging software (Nikon Tec Corporation, Tokyo, Japan). Quantitative analyses were conducted using the TSView software, version 6.1.3.2 (Tucsen Imaging Technology Co. Ltd., Fuzhou, Fujian, China).

Leaf relative water content (RWC) was calculated, after determining turgid weight (TW), fresh weight $(\mathrm{FW})$, and dry weight (DW) of two leaf discs, $1.0 \mathrm{~cm}$ in diameter, using the equation: $\mathrm{RWC}=100[(\mathrm{FW}-\mathrm{DW}) /(\mathrm{TW}-\mathrm{DW})]$ (Barrs, 1968).

The predawn leaf water potential $\left(\Psi_{\mathrm{w}}\right)$ was assessed with a Scholander pressure chamber, model 600 (PMS Instrument Company, Albany, OR, USA).

For determination of the leaf $\mathrm{Si}$ contents, a colorimetric silicomolybdic acid complex test was used, indicating Si with a yellow color (Korndörfer et al., 2004).

Photosynthetic pigments were extracted with dimethyl sulfoxide, and five leaf discs, $0.5 \mathrm{~cm}$ in diameter, were removed. The disks were then macerated in the dark with $7.0 \mathrm{~mL}$ of the solvent, at $25^{\circ} \mathrm{C}$, for a period of 72 hours and, subsequently, read in a spectrophotometer. The concentrations of chlorophyll and carotenoids were calculated according to the equations proposed by Lichtenthaler \& Welburn (1983).
To verify the stability of the membranes, an electrolyte leakage technique was implemented using a conductivity meter, model SX723 (Shanghai San-Xin Instrumentation, Inc., Shanghai, China), following the methodology described by Bajji et al. (2001).

The fluorescence transient OJIP emission was measured between 7:00 and 9:00 AM, using a portable fluorimeter Pocket PEA (Hansatech Instruments Ltd., King's Lynn, Norfolk, UK). Before evaluation, the leaves were adapted to the dark for $30 \mathrm{~min}$. The fluorescence emission of the leaves was induced by a saturating pulse of red light of $3,500 \mu \mathrm{mol}$ photons $\mathrm{m}^{-2} \mathrm{~s}^{-1}$. The JIP measurements were analyzed as proposed by Strasser et al. (2004). The following parameters were chosen: density of the active reaction centers of photosystem II (PSII) (RC/ABS), conformation term for the primary photochemistry $\left(\varphi_{\mathrm{P} 0} /\left(1-\varphi_{\mathrm{P} 0}\right)\right)$, conformation term for the reactions that were not dependent on light beyond the reduced quinone $a\left(\Psi_{0} /\left(1-\Psi_{0}\right)\right)$, conformation term for the reactions of the reduced intersystem until reduction of the final electron acceptor of photosystem I (PSI) $\left(\delta_{\mathrm{Ro}} /\left(1-\delta_{\mathrm{R} 0}\right)\right)$, and the performance index (potential) for energy conservation from an exciton until reduction of the final acceptor of PSI ( $\left.\mathrm{PI}_{\text {TOTAL }}\right)$.

Gas exchange measurements were performed on the same leaves used for the analysis of fluorescence, between 8:00 and 10:00 AM, with an infrared gas analyzer, model LI-6400 (LI-COR, Lincoln, NE, USA), under an irradiance of $1,000 \mu \mathrm{mol}$ photons $\mathrm{m}^{-2} \mathrm{~s}^{-1}$. With the infrared gas analyzer, it was possible to obtain $\mathrm{CO}_{2}$ assimilation (A), transpiration (E), stomatal conductance $\left(\mathrm{g}_{\mathrm{s}}\right)$, and intercellular concentration of $\mathrm{CO}_{2}$ $\left(\mathrm{C}_{\mathrm{i}}\right)$. From these variables, the instant carboxylation efficiency $\left(\mathrm{A} / \mathrm{C}_{\mathrm{i}}\right)$ and intrinsic water use efficiency $(\mathrm{A} / \mathrm{gs})$ were calculated.

For the extraction of the antioxidant enzymes, $200 \mathrm{mg}$ of the leaf tissue were grinded with liquid nitrogen using a mortar and pestle, then homogenized in $100 \mathrm{mmol} \mathrm{L}^{-1}$ ( $\mathrm{pH}$ 6.8) potassium phosphate buffer containing $0.1 \mathrm{mmol} \mathrm{L}^{-1}$ EDTA-Na $2,10 \mathrm{mmol} \mathrm{L}^{-1}$ ascorbic acid, and polyvinylpolypyrrolidone (PVPP) $1 \%(\mathrm{~W} / \mathrm{V})$. The homogenate was centrifuged at $12,000 \mathrm{~g}$ for $15 \mathrm{~min}$ at $4^{\circ} \mathrm{C}$. The resulting supernatant was used to assay the catalase (CAT), ascorbate peroxidase (APX), guaiacol peroxidase (POD), and polyphenol oxidase (PPO) activities and to quantify the phenols.

Pesq. agropec. bras., Brasília, v.51, n.3, p.215-223, abr. 2016 DOI: 10.1590/S0100-204X2016000300003 
The CAT activity (E.C. 1.11.1.6) was determined according to the methodology described by Havir \& McHale (1989) with modifications. The reaction mixture $(2.15 \mathrm{~mL})$ was obtained in $100 \mathrm{mmol} \mathrm{L}^{-1}$ sodium phosphate buffer ( $\mathrm{pH} 7.0)$ with $20 \mathrm{mmol} \mathrm{L}^{-1} \mathrm{H}_{2} \mathrm{O}_{2}$, and the reaction was started by adding $50 \mu \mathrm{L}$ of enzyme extract. The activity was determined by monitoring the initial rate of disappearance of $\mathrm{H}_{2} \mathrm{O}_{2}$ at $240 \mathrm{~nm}$, after $30 \mathrm{~s}$, at $28^{\circ} \mathrm{C}$. The extinction coefficient of $\mathrm{H}_{2} \mathrm{O}_{2}$ was $36 \mathrm{mmol} \mathrm{L}^{-1} \mathrm{~cm}^{-1}$ (Nakano \& Asada, 1981).

The APX activity (EC 1.11.1.11) was determined according to the methodology of Nakano \& Asada (1981) with modifications. The reaction mixture $(2.5 \mathrm{~mL})$ for APX contained $100 \mathrm{mmol} \mathrm{L}^{-1}$ sodium phosphate buffer (pH 7.0) with $10 \mathrm{mmol} \mathrm{L}^{-1}$ ascorbic acid and $2.0 \mathrm{mmol} \mathrm{L}^{-1} \mathrm{H}_{2} \mathrm{O}_{2}$. Briefly, the reaction was started by adding $30 \mu \mathrm{L}$ of enzyme extract. The oxidation of $\mathrm{H}_{2} \mathrm{O}_{2}$, which was dependent on ascorbic acid, was measured by the decrease in absorbance at $285 \mathrm{~nm}$, after $3 \mathrm{~min}$, at $28^{\circ} \mathrm{C}$. The extinction coefficient for $\mathrm{H}_{2} \mathrm{O}_{2}$ was $2.8 \mathrm{mmol} \mathrm{L}^{-1} \mathrm{~cm}^{-1}$ (Nakano \& Asada, 1981).

The POD activity (EC 1.11.1.7) was determined according to the methodology described by Cakmak et al. (1993) with modifications. The reaction medium $(2.15 \mathrm{~mL})$ consisted of $100 \mathrm{mmol} \mathrm{L}^{-1}$ sodium phosphate buffer (pH 7.0) with $20 \mathrm{mmol} \mathrm{L}^{-1}$ guaiacol and $20 \mathrm{mmol} \mathrm{L}-1 \mathrm{H}_{2} \mathrm{O}_{2}$. The reaction was started with $50 \mu \mathrm{L}$ of enzyme extract. The increase in absorbance due to guaiacol oxidation was recorded at $470 \mathrm{~nm}$ after $2 \mathrm{~min}$ of reaction at $28^{\circ} \mathrm{C}$. The $\mathrm{H}_{2} \mathrm{O}_{2}$ extinction coefficient was $26.6 \mathrm{mmol} \mathrm{L}^{-1} \mathrm{~cm}^{-1}$.

The PPO activity (EC 1.30.3.1) was evaluated according to Cañal et al. (1988) with some modifications. The reaction mixture $(2.2 \mathrm{~mL})$ consisted of $0.02 \mathrm{~mol} \mathrm{~L}^{-1}$ sodium phosphate buffer $(\mathrm{pH} 6.8)$ and $0.2 \mathrm{~mol} \mathrm{~L}^{-1}$ catechol. The reaction was started with $20 \mu \mathrm{L}$ of enzyme extract. The increase in absorbance was recorded at $420 \mathrm{~nm}$ after $2 \mathrm{~min}$ of reaction at $28^{\circ} \mathrm{C}$. The total activity for this enzyme was expressed as the increase in absorbance per minute.

To measure the concentrations of phenolic compounds in the extracts, the Folin-Ciocalteu reagent was used with gallic acid calibration, according to the methodology proposed by Singleton \& Rossi (1965) with modifications. Under stirring, $50 \mu \mathrm{L}$ of extract, $1,250 \mu \mathrm{L}$ of ultrapure water, and $200 \mu \mathrm{L}$ of Folin-Ciocalteu reagent were added. After $4 \mathrm{~min}$, $1.0 \mathrm{~mL}$ of $15 \% \mathrm{Na}_{2} \mathrm{CO}_{3}$ was added, and the mixture was stirred for 2 hours at $25^{\circ} \mathrm{C}$. Absorbance was measured at $760 \mathrm{~nm}$.

The results were subjected to analysis of variance (Anova), and the mean values were compared by Tukey's test, at $5 \%$ probability. When there was a significant effect of the interaction between irrigation and Si concentration, interaction slicing was performed. All analyses were carried out using the Assistat software, version 7.6 beta (Universidade Federal de Campina Grande, Campina Grande, PB, Brazil).

\section{Results and Discussion}

The relative water content did not significantly differ among treatments, staying at approximately $85 \%$ (Table 1). Although higher water contents were expected in irrigated plants than in nonirrigated ones, as reported for other species (Shen et al., 2010; Ming et al., 2012), this was not the case for the cacao tree, corroborating the results obtained by Almeida et al. (2002). Starch grains were found in abundance in the central vein after 20 days of the nonirrigated treatment (Figure $1 \mathrm{~A}$ ), but these structures were scarce in the irrigated plants (Figure $1 \mathrm{~B}$ ). Regarding other soluble carbohydrates, the accumulation of starch does not necessarily facilitate osmoregulation, although the starch grains can be deployed rapidly to provide soluble sugars in tissue subjected to water stress (Krasensky \& Jonak, 2012).

Even though water deficit usually leads to a depletion in starch content, such that there is an accumulation of soluble sugars in leaves (Basu et al., 2007), the higher amounts of starch grains in the leaves of cacao plants can indicate a response to maintain their water content. Under a more prolonged drought condition, the higher amount of starch grains observed in the leaves of plants under water stress may be used as a reserve and, therefore, increase the production of more osmotically active sugars through the degradation of the starch molecule. Almeida et al. (2002) evaluated the effects of water stress in five-month-old seedlings of eight cacao genotypes grafted onto the common cacao variety and found that drought resistance occurred, at least partially, through osmotic adjustment in most genotypes and that there was a significant increase in leaf concentration of $\mathrm{K}$ and $\mathrm{P}$ during the dehydration process of some genotypes at $\Psi_{\mathrm{w}}$ of $-1.5 \mathrm{MPa}$. 
The presence of mucilage in leaf epidermal cells (Figure $1 \mathrm{C}$ ) and of secretory ducts in the cortex and medulla of the central vein of cacao (Figure 1 D) indicates that the plant is trying to retain water to maintain its cell turgor and anatomical structure. There was no change in the thickness of: epidermis of the adaxial surface, palisade parenchyma, spongy parenchyma, epidermis of the abaxial surface, or leaf blade (Table 1). In addition, in both water conditions, the $\mathrm{Si}$ concentration did not affect the anatomy of the cacao leaves. However, the water potential was affected by irrigation and Si concentration, although no significant interaction was observed between these factors. The water potential was lower in nonirrigated plants in comparison with irrigated plants, as reported previously in the literature (Almeida et al., 2002; Bae et al., 2008).

The application of Si reduced the water potential at the highest leaf concentration of $\mathrm{SiO}_{2}$, i.e., $3.0 \mathrm{mg} \mathrm{mL}^{-1}$ (Table 1). This response differs from those found in the literature for other species, in which Si increased or maintained the leaf water potential (Ming et al., 2012). In the present study with cacao, the reduction of the leaf water potential at the highest dosage could be explained by the possible increase in the internal concentration of solutes and the stiffening of the cell wall promoted by the leaf application of Si. It should be noted that the differences in water potential observed among these studies may be related to the $\mathrm{Si}$ leaf concentrations used in each one.

The Si leaf content in nonirrigated plants was $62 \%$ lower than that in irrigated plants (Table 1), which can be attributed to the fact that this mineral nutrient can be absorbed by the soil and translocated in the plant along with the water (Ma et al., 2001). The plants that were irrigated but that did not receive leaf application of Si had Si leaf contents above $1 \%$, suggesting that they naturally accumulate this mineral nutrient (Ma et al., 2001).

The content of photosynthetic pigments did not change with treatments (Table 1). There is no consensus in the literature on the effect of $\mathrm{Si}$ on the content of photosynthetic pigments, which may be related to the intrinsic characteristics of each species as well as to the different experimental conditions used in the different studies. For example, in soybean (Glycine max L.), the leaf application of Si did not alter the chlorophyll content in nonirrigated plants (Shen et al., 2010), whereas in rice (Oryza sativa L.), the addition of $1.50 \mathrm{mmol} \mathrm{L}^{-1} \mathrm{Si}$ in nonirrigated soil increased the total chlorophyll content (Chen et al., 2011).

The leaf content of total phenols was higher in nonirrigated plants (Table 1). Furthermore, no interaction was observed between irrigation and $\mathrm{Si}$ concentration. The accumulation of phenols in leaves may help to maintain the photosynthetic pigment content because phenols can filter ultraviolet light, which can mitigate the detrimental effects of radiation on chloroplasts and other cell structures (Shen et al., 2010).

In nonirrigated plants, electrolyte leakage was reduced with the application of Si (Table 2). These results reinforce the positive effect of $\mathrm{Si}$ on the stabilization and structural maintenance of the plasma membrane in nonirrigated plants, which reduces the loss of soluble solids and contributes to osmotic adjustment (Ming et al., 2012).

Table 1. Effects of water supply and $\mathrm{Si}$ concentration on the thickness of the epidermis of the adaxial surface (AD), the palisade parenchyma (PP), the spongy parenchyma (SP), the epidermis of the abaxial surface (AB), and the leaf blade (LB), as well as relative water content (RWC), water potential $\left(\Psi_{\mathrm{w}}\right)$, Si content, photosynthetic pigments, and total phenolics in the leaves of cacao (Theobroma cacao $)^{(1)}$.

\begin{tabular}{|c|c|c|c|c|c|c|c|c|c|c|c|c|c|}
\hline Treatment & $\mathrm{AD}$ & PP & SP & $\mathrm{AB}$ & LB & RWC & $\Psi_{\mathrm{w}}$ & $\mathrm{Si}$ & $\begin{array}{l}\text { Chloro- } \\
\text { phyll } a\end{array}$ & $\begin{array}{l}\text { Chloro- } \\
\text { phyll } b\end{array}$ & $\begin{array}{c}\text { Total } \\
\text { chlorophyll }\end{array}$ & $\begin{array}{l}\text { Carote- } \\
\text { noids }\end{array}$ & Phenols $^{(2)}$ \\
\hline & --------- & -------- n n n & -( $(\mu \mathrm{m})----$ & -------. & ---------- & $(\%)$ & $(-\mathrm{MPa})$ & $(\%)$ & --- & $--\left(\mathrm{mg} \mathrm{g}^{-}\right.$ & dry matter)- & ----------- & $\left(\mu \mathrm{g} \mathrm{g}^{-1}\right)$ \\
\hline Irrigated & $19.43^{\text {ns }}$ & $35.61^{\mathrm{ns}}$ & $64.62^{\text {ns }}$ & $9.41^{\mathrm{ns}}$ & $128.89^{\text {ns }}$ & $84.14^{\mathrm{ns}}$ & $0.36 \mathrm{a}$ & $1.07 \mathrm{a}$ & $4.94^{\mathrm{ns}}$ & $1.01^{\mathrm{ns}}$ & $8.06^{\mathrm{ns}}$ & $2.93^{\text {ns }}$ & $10.18 \mathrm{~b}$ \\
\hline Nonirrigated & 18.82 & 34.61 & 59.08 & 9.70 & 122.50 & 84.79 & $0.85 \mathrm{~b}$ & $0.66 \mathrm{~b}$ & 5.45 & 1.07 & 8.90 & 3.21 & $14.08 \mathrm{a}$ \\
\hline $0.0 \mathrm{mg} \mathrm{mL}^{-1} \mathrm{SiO}_{2}$ & $18.22^{\text {ns }}$ & $33.03^{\text {ns }}$ & $58.37^{\text {ns }}$ & $9.18^{\mathrm{ns}}$ & $119.05^{\mathrm{ns}}$ & $86.23^{\text {ns }}$ & $0.50 \mathrm{a}$ & $0.99^{\text {ns }}$ & $5.00^{\text {ns }}$ & $1.03^{\mathrm{ns}}$ & $8.16^{\mathrm{ns}}$ & $3.07^{\mathrm{ns}}$ & $9.88 \mathrm{~b}$ \\
\hline $1.5 \mathrm{mg} \mathrm{mL}^{-1} \mathrm{SiO}_{2}$ & 20.04 & 35.93 & 62.06 & 9.75 & 128.02 & 84.84 & $0.59 \mathrm{ab}$ & 1.05 & 5.18 & 1.03 & 8.45 & 3.03 & $12.94 \mathrm{a}$ \\
\hline $3.0 \mathrm{mg} \mathrm{mL}^{-1} \mathrm{SiO}_{2}$ & 19.13 & 36.37 & 65.12 & 9.72 & 130.02 & 82.31 & $0.72 b$ & 0.91 & 5.41 & 1.06 & 8.83 & 3.10 & $13.56 \mathrm{a}$ \\
\hline
\end{tabular}

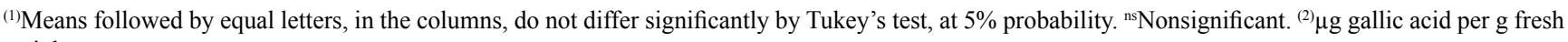
weight. 
Because the fluorescence emission of chlorophyll $a$ is dependent on membrane structures, such as thylakoids (that allow a more stable anchoring of photosynthetic pigments), the greater the thylakoid structure is, the better the stabilization of the photosystems will be in the membranous structure of the chloroplasts. Therefore, in nonirrigated plants, Si application, which contributes to the stabilization of the membranes of nonirrigated plants, changes fluorescence emission (Table 2). The application with the concentration of $1.5 \mathrm{mg} \mathrm{mL}^{-1} \mathrm{Si}$ increased RC/ABS in the nonirrigated plants. This result indicates that the density of the active reaction centers is based on the amount of chlorophyll. Consequently, a decrease in this value indicates an increase in the size of the antenna system needed to supply each reaction center (Strasser et al., 2004).

The electron flow beyond $\mathrm{Q}_{\mathrm{A}^{-}}$up to the final electron acceptors of PSI was not affected because $\Psi_{0} /\left(1-\Psi_{0}\right)$ and $\delta_{\mathrm{R} 0} /\left(1-\delta_{\mathrm{R} 0}\right)$ showed no significant differences. These parameters contributed to a greater

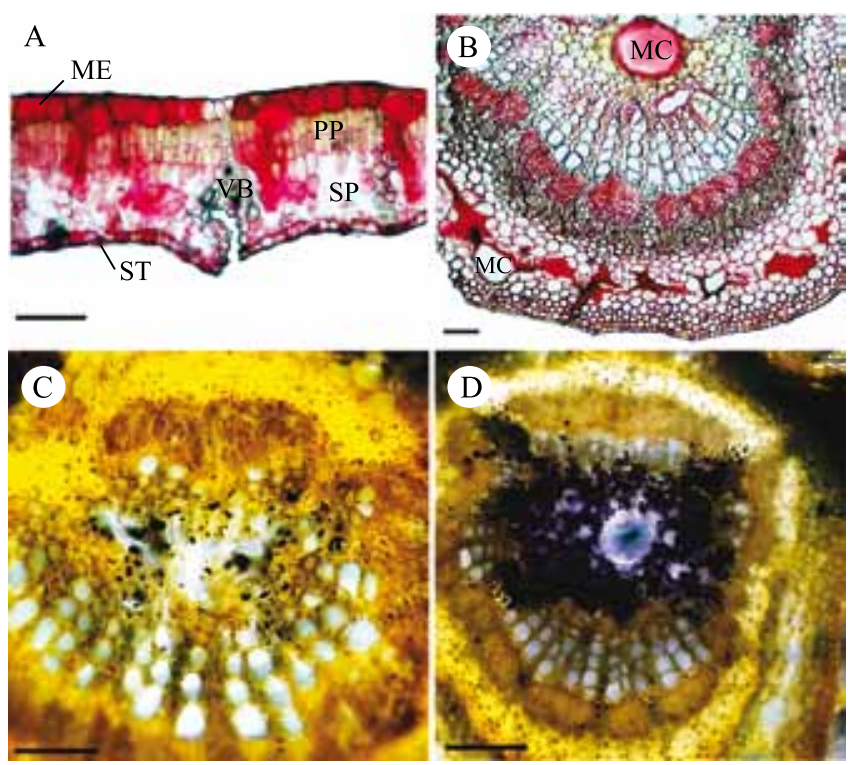

Figure 1. Cross-sections of the leaf blades of cacao (Theobroma cacao) subjected to histochemical testing. Ruthenium red reagent was used to indicate the accumulation of mucilage in the epidermal cells (A) and in the secretory canals of the central vein (B), whereas Lugol's staining indicated the presence of starch grains (black color) in the irrigated (C) and in the nonirrigated plants (D). ME, mucilaginous epidermis; ST, stomata; VB, vascular bundle; PP, palisade parenchyma; SP, spongy parenchyma; and MC, mucilage canal. Scale bar $=100 \mu \mathrm{m}$. $\varphi \mathrm{P}_{0} /\left(1-\varphi \mathrm{P}_{0}\right)$ and $\mathrm{PI}_{\text {TотAL }}$ in the nonirrigated plants subjected to a concentration of $1.5 \mathrm{mg} \mathrm{mL}^{-1} \mathrm{Si}$; the latter is considered the most sensitive parameter of the JIP test (Mehta et al., 2010). Without Si application, the $\mathrm{PI}_{\text {TOTAL }}$ of the nonirrigated plants did not differ significantly from that of the irrigated plants, showing that cacao plants under water deficit have a high energy gain (ATP and NADPH). Under limiting root water conditions, the cacao plants that received $1.5 \mathrm{mg} \mathrm{L}^{-1}$ had higher values for $\mathrm{PI}_{\mathrm{TOTAL}}$, showing that Si improves the photochemical efficiency of the species. An improvement in photochemical efficiency with $\mathrm{Si}$ application was also reported for other species subjected to water deficit (Xu \& Xu, 2005; Chen et al., 2011).

For other the parameters, such as stomatal conductance, transpiration and internal $\mathrm{CO}_{2}$

Table 2. Average density values of the active reaction centers of photosystem II (RC/ABS), the conformation term for the primary photochemistry, the conformation term for the reactions that are not dependent on light beyond the reduced quinone $a$, the conformation term for the reactions of the reduced intersystem of the final electron acceptor of photosystem I, and the performance index (potential) for energy conservation from an exciton until reduction of the final acceptor of PSI ( $\left.\mathrm{PI}_{\mathrm{TOTAL}}\right)$ in the leaves of cacao $(\text { Theobroma cacao })^{(1)}$.

\begin{tabular}{lccc}
\hline Treatment & \multicolumn{3}{c}{ Concentrations of $\mathrm{SiO}_{2}\left(\mathrm{mg} \mathrm{mL}^{-1}\right)$} \\
\cline { 2 - 4 } Irrigated & 0.0 & 1.5 & 3.0 \\
Nonirrigated & $10.63 \mathrm{bA}$ & $9.60 \mathrm{aA}$ & $10.54 \mathrm{aA}$ \\
& $19.52 \mathrm{aA}$ & $9.59 \mathrm{aB}$ & $11.06 \mathrm{aB}$ \\
Irrigated & \multicolumn{3}{c}{$\mathrm{RC} / \mathrm{ABS}$} \\
Nonirrigated & $1.99 \mathrm{aA}$ & $1.84 \mathrm{bA}$ & $1.98 \mathrm{aA}$ \\
\hline \multicolumn{4}{c}{ Primary photochemistry $\left[\varphi_{\mathrm{Po}} /\left(1-\varphi_{\mathrm{P}}\right)\right]$} \\
Irrigated & $3.42 \mathrm{aA}$ & $3.32 \mathrm{bA}$ & $3.48 \mathrm{aA}$ \\
Nonirrigated & $3.34 \mathrm{aB}$ & $3.96 \mathrm{aA}$ & $3.42 \mathrm{aAB}$ \\
\hline & \multicolumn{4}{c}{ Reduced quinone a $\left[\Psi_{0} /\left(1-\Psi_{0}\right)\right]$} \\
Irrigated & $0.42^{\mathrm{ns}}$ & 0.32 & 0.39 \\
Nonirrigated & 0.30 & 0.45 & 0.39 \\
\hline & Final electron acceptor of photosystem I $\left[\delta_{\mathrm{R} 0} /\left(1-\delta_{\mathrm{R} 0}\right)\right]$ \\
Irrigated & $0.90^{\text {ns }}$ & 0.91 & 0.93 \\
Nonirrigated & 1.20 & 0.93 & 1.10 \\
\hline \multirow{4}{*}{ Irrigated } & $2.30 \mathrm{aA}$ & $1.62 \mathrm{bA}$ & $2.30 \mathrm{aA}$ \\
Nonirrigated & $1.74 \mathrm{aB}$ & $3.21 \mathrm{aA}$ & $2.72 \mathrm{aAB}$ \\
\hline
\end{tabular}

${ }^{(1)}$ Means followed by equal letters, lowercase between water supply treatments and uppercase between Si concentration treatments, do not differ by Tukey's test, at $5 \%$ probability. ${ }^{\text {ns }}$ Nonsignificant. 
concentration, there was no interaction between irrigation and Si concentration (Table 3). Compared with the irrigated plants, the nonirrigated ones showed lower stomatal conductance and transpiration. Moreover, the internal $\mathrm{CO}_{2}$ concentration was higher in nonirrigated plants. The reduction in the stomatal aperture in plants under water deficit reduced transpiration and contributed to the increase in internal carbon concentration. This was possibly caused by the photorespiratory activity of plants in drought conditions (Singh et al., 2011) or by the impairment of water-dependent enzyme reactions associated with the Calvin-Benson cycle.

Regarding $\mathrm{Si}$ concentrations, differences were only observed between the concentrations of 1.5 and $3.0 \mathrm{mg} \mathrm{mL}^{-1}$ for the parameters stomatal conductance and transpiration; the concentration of $3.0 \mathrm{mg} \mathrm{mL}^{-1}$ showed the lowest values for both of these parameters (Table 3). The $3.0 \mathrm{mg} \mathrm{mL}^{-1}$ concentration decreased stomatal conductance, reducing transpiration due to the formation of a thick layer of Si on the leaf surface that hindered the gas diffusion process. Trenholm et al. (2004) suggested that silicate crystals are deposited on epidermal cells to form a barrier that can reduce water loss through the cuticle.

In nonirrigated plants, the concentration of $1.5 \mathrm{mg} \mathrm{mL}^{-1}$ provided the best photosynthesis rate, water use efficiency, and carboxylation efficiency (Table 4), which is in agreement with other studies reporting the positive effects of $\mathrm{Si}$ on gas exchange (Shen et al., 2010; Ming et al., 2012).

Considering the CAT, APX, POD, and PPO activities, the application of $1.5 \mathrm{mg} \mathrm{mL}^{-1} \mathrm{Si}$ on nonirrigated cacao plants proved to be beneficial, as it resulted in values

Table 3. Effects of water supply and Si concentration on stomatal conductance $\left(\mathrm{g}_{\mathrm{s}}\right)$, transpiration $(\mathrm{E})$, and internal $\mathrm{CO}_{2}$ concentration $(\mathrm{Ci})$ in the leaves of cacao (Theobroma (acao $)^{(1)}$.

\begin{tabular}{lccc}
\hline Treatment & $\begin{array}{c}\mathrm{g}_{\mathrm{s}} \\
\left(\mathrm{mol} \mathrm{H}_{2} \mathrm{O} \mathrm{m}^{-2} \mathrm{~s}^{-1}\right)\left(\mathrm{mmol} \mathrm{H}_{2} \mathrm{O} \mathrm{m}^{-2} \mathrm{~s}^{-1}\right)\end{array}$ & $\begin{array}{c}\mathrm{C}_{\mathrm{i}} \\
\left(\mu \mathrm{mol} \mathrm{CO}_{2} \mathrm{~mol}^{-1}\right)\end{array}$ \\
\hline Irrigated & $0.047 \mathrm{a}$ & $1.68 \mathrm{a}$ & $238 \mathrm{~b}$ \\
Nonirrigated & $0.013 \mathrm{~b}$ & $0.46 \mathrm{~b}$ & $244 \mathrm{a}$ \\
\hline $0.0 \mathrm{mg} \mathrm{mL}^{-1} \mathrm{SiO}_{2}$ & $0.029 \mathrm{ab}$ & $1.06 \mathrm{ab}$ & $242^{\mathrm{ns}}$ \\
$1.5 \mathrm{mg} \mathrm{mL}^{-1} \mathrm{SiO}_{2}$ & $0.034 \mathrm{a}$ & $1.23 \mathrm{a}$ & 239 \\
$3.0 \mathrm{mg} \mathrm{mL}^{-1} \mathrm{SiO}_{2}$ & $0.025 \mathrm{~b}$ & $0.93 \mathrm{~b}$ & 243 \\
\hline
\end{tabular}

(1)Means followed by equal letters, in the columns, do not differ significan-

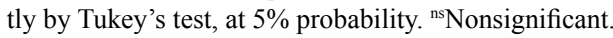

near or equal to those of irrigated plants without the application of $\mathrm{Si}$ (Table 4). The application of Si during water deficit decreased the CAT activity, suggesting that this enzyme can diminish the photorespiratory activity (Shen et al., 2010). The highest PPO enzyme activity may have acted as a sink for the additional light energy not used in the photochemical reaction. Therefore, it is expected that higher PPO activity can increase stress tolerance by reducing the photooxidation damage. In the present study, the plants under water deficit without Si showed low PPO activity in their leaves.

Stomatal density was greater in cacao plants under water deficit and lower in plants treated with $3.0 \mathrm{mg} \mathrm{mL}^{-1} \mathrm{Si}$ (Table 4). Lower stomatal density

Table 4. Photosynthesis (A), intrinsic water use efficiency $\left(\mathrm{A} / \mathrm{g}_{\mathrm{s}}\right)$, instant carboxylation efficiency $\left(\mathrm{A} / \mathrm{C}_{\mathrm{i}}\right)$, catalase (CAT) activity, ascorbate peroxidase (APX) activity, guaiacol peroxidase (POD) activity, polyphenol oxidase (PPO) activity, and stomatal density of cacao (Theobroma cacao) leaves as affected by water supply and Si concentration ${ }^{(1)}$.

\begin{tabular}{|c|c|c|c|}
\hline \multirow[t]{2}{*}{ Treatment } & \multicolumn{3}{|c|}{ Concentrations of $\mathrm{SiO}_{2}\left(\mathrm{mg} \mathrm{mL}^{-1}\right)$} \\
\hline & 0.0 & 1.5 & 3.0 \\
\hline & \multicolumn{3}{|c|}{$\mathrm{A}\left(\mu \mathrm{mol} \mathrm{CO} \mathrm{C}^{-2} \mathrm{~s}^{-1}\right)$} \\
\hline Irrigated & $4.28 \mathrm{aA}$ & $4.28 \mathrm{aA}$ & $4.10 \mathrm{aA}$ \\
\hline \multirow[t]{2}{*}{ Nonirrigated } & $1.62 \mathrm{bB}$ & $2.44 \mathrm{bA}$ & $1.13 \mathrm{bB}$ \\
\hline & \multicolumn{3}{|c|}{$\mathrm{A} / \mathrm{g}_{\mathrm{s}}\left(\mu \mathrm{mol} \mathrm{CO} \mathrm{mol}^{-1} \mathrm{H}_{2} \mathrm{O}\right)$} \\
\hline Irrigated & $70.29 \mathrm{aA}$ & $62.41 \mathrm{aA}$ & $70.32 \mathrm{aA}$ \\
\hline \multirow[t]{2}{*}{ Nonirrigated } & $39.51 \mathrm{bB}$ & $79.52 \mathrm{aA}$ & $32.43 \mathrm{bB}$ \\
\hline & \multicolumn{3}{|c|}{$\mathrm{A} / \mathrm{Ci}\left(\mathrm{mol}\right.$ air $\left.\mathrm{m}^{-2} \mathrm{~s}^{-1}\right)$} \\
\hline Irrigated & $0.0138 \mathrm{aA}$ & $0.0136 \mathrm{aA}$ & $0.0133 \mathrm{aA}$ \\
\hline \multirow[t]{2}{*}{ Nonirrigated } & $0.0048 \mathrm{bB}$ & $0.0078 \mathrm{bA}$ & $0.0033 b \mathrm{~b}$ \\
\hline & \multicolumn{3}{|c|}{ CAT $\left(\mu \mathrm{mol} \mathrm{min} \mathrm{m}^{-1} \mathrm{~g}^{-1}\right.$ fresh weight $)$} \\
\hline Irrigated & $0.67 \mathrm{bA}$ & $0.72 \mathrm{aA}$ & $0.20 \mathrm{bB}$ \\
\hline \multirow[t]{2}{*}{$\underline{\text { Nonirrigated }}$} & $1.00 \mathrm{aA}$ & $0.38 \mathrm{bB}$ & $0.94 \mathrm{aA}$ \\
\hline & \multicolumn{3}{|c|}{ APX $\left(\mu \mathrm{mol} \mathrm{min}{ }^{-1} \mathrm{~g}^{-1}\right.$ fresh weight $)$} \\
\hline Irrigated & $2.11 \mathrm{aA}$ & $1.40 \mathrm{bB}$ & $0.98 \mathrm{bB}$ \\
\hline \multirow[t]{2}{*}{ Nonirrigated } & $0.66 \mathrm{bC}$ & $2.02 \mathrm{aA}$ & $1.42 \mathrm{aB}$ \\
\hline & \multicolumn{3}{|c|}{ POD $\left(\mu \mathrm{mol} \mathrm{min} \mathrm{min}^{-1} \mathrm{~g}^{-1}\right.$ fresh weight $)$} \\
\hline Irrigated & $0.72 b B$ & $1.09 \mathrm{aA}$ & $0.39 \mathrm{bC}$ \\
\hline \multirow[t]{2}{*}{ Nonirrigated } & $1.07 \mathrm{aA}$ & $0.19 \mathrm{bC}$ & $0.65 \mathrm{aB}$ \\
\hline & \multicolumn{3}{|c|}{ PPO (UA min ${ }^{-1} \mathrm{~g}^{-1}$ fresh weight $)$} \\
\hline Irrigated & $9.59 \mathrm{aA}$ & $8.90 \mathrm{aA}$ & $10.52 \mathrm{aA}$ \\
\hline \multirow[t]{2}{*}{ Nonirrigated } & $5.90 \mathrm{bB}$ & $10.45 \mathrm{aA}$ & $7.20 \mathrm{bB}$ \\
\hline & \multicolumn{3}{|c|}{ Number of stomata per millimeter } \\
\hline Irrigated & $890 \mathrm{bA}$ & $881 \mathrm{bA}$ & $890 \mathrm{aA}$ \\
\hline Nonirrigated & $976 \mathrm{aA}$ & $948 \mathrm{aA}$ & $858 \mathrm{aB}$ \\
\hline
\end{tabular}

${ }^{(1)}$ Means followed by equal letters, lowercase between water supply treatments and uppercase between $\mathrm{Si}$ concentration treatments, do not differ

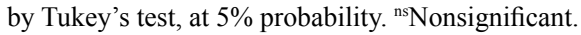


can interfere with water transport regulation and reduce gas exchange efficiency, which may reduce the photosynthetic rate and the intrinsic water use efficiency, whereas greater stomatal density can be a result of reduced leaf expansion, which can be caused by reduced turgor pressure under limited water conditions. Studies have shown that environmental factors, such as light, can regulate the development of the stomata (Nadeau \& Sack, 2002). According to Luz (2006), the presence of a Si layer on leaf surfaces can change light reflectivity. Therefore, higher concentrations of $\mathrm{Si}$, such as that of $3.0 \mathrm{mg} \mathrm{mL}^{-1}$, suggest the presence of a thicker layer of Si on leaf surfaces, which would affect the transmittance of light, reducing the formation of stomata and their density in the leaves.

\section{Conclusions}

1. Leaf application of silicon $\left(\mathrm{SiO}_{2}\right)$ improves the tolerance of cacao (Theobroma cacao) plants to water deficit.

2. The concentration of $1.5 \mathrm{mg} \mathrm{mL} \mathrm{mL}^{-1} \mathrm{SiO}_{2}$ is considered optimal in increasing photosynthetic rate, water use efficiency, and carboxylation efficiency, besides mitigating the effect of oxidative stress.

\section{References}

ALMEIDA, A.-A.F. de; BRITO, R.C.T.; AGUILAR, M.A.G.; VALLE, R.R. Water relations' aspects of Theobroma cacao L. clones. Agrotrópica, v.14, p.35-44, 2002.

ALMEIDA, A.-A.F. de; VALLE, R.R. Cacao: ecophysiology of growth and production. In: MATTA, F. da (Ed.). Ecophysiology of tropical tree crops. New York: Nova Science Publishers, 2010. v.1, p.37-70. (Agriculture issues and policies).

ALVIM, P. de T. Las necesidades de agua del cacao. Turrialba, v.10, p.6-16, 1960.

BAE, H.; KIM, S.-H.; KIM, M.S.; SICHER, R.C.; LARY, D.; STREM, M.D.; NATARAJAN, S.; BAILEY, B.A. The drought response of Theobroma cacao (cacao) and the regulation of genes involved in polyamine biosynthesis by drought and other stresses. Plant Physiology and Biochemistry, v.46, p.174-188, 2008. DOI: 10.1016/j.plaphy.2007.10.014.

BAJJI, M.; KINET, J.-M.; LUTTS, S. The use of the electrolyte leakage method for assessing cell membrane stability as a water stress tolerance test in durum wheat. Plant Growth Regulation, v.36, p.61-70, 2001. DOI: 10.1023/A:1014732714549.

BARRS, H.D. Effect of cyclic variations in gas exchange under constant environmental conditions on the ratio of transpiration to net photosynthesis. Physiologia Plantarum, v.21, p.918-929, 1968. DOI: 10.1111/j.1399-3054.1968.tb07318.x.
BASU, P.S.; ALI, M.; CHATURVEDI, S.K. Osmotic adjustment increases water uptake, remobilization of assimilates and maintains photosynthesis in chickpea under drought. Indian Journal of Experimental Biology, v.45, p.261-267, 2007.

CAKMAK, I.; STRBAC, D.; MARSCHNER, H. Activities of hydrogen peroxide-scavenging enzymes in germinating wheat seeds. Journal of Experimental Botany, v.44, p.127-132, 1993. DOI: $10.1093 / \mathrm{jxb} / 44.1 .127$.

CAÑAL, M.J.; TAMÉS, R.S.; FERNÁNDEZ, B. Peroxidase and polyphenol oxidase activities in Cyperus esculentus leaves following glyphosate applications. Physiologia Plantarum, v.74, p.125-130, 1988. DOI: 10.1111/j.1399-3054.1988.tb04952.x.

CHEN, W.; YAO, X.; CAI, K.; CHEN, J. Silicon alleviates drought stress of rice plants by improving plant water status, photosynthesis and mineral nutrient absorption. Biological Trace Element Research, v.142, p.67-76, 2011. DOI: 10.1007/s12011-010-8742-X. EPSTEIN, E. Silicon. Annual Review of Plant Physiology and Plant Molecular Biology, v.50, p.641-664, 1999. DOI: 10.1146/ annurev.arplant.50.1.641.

GAO, X.; ZOU, C.; WANG, L.; ZHANG, F. Silicon decreases transpiration rate and conductance from stomata of maize plants. Journal of Plant Nutrition, v.29, p.1637-1647, 2006. DOI: $10.1080 / 01904160600851494$.

HAVIR, E.A.; McHALE, N.A. Regulation of catalase activity in leaves of Nicotiana sylvestris by high $\mathrm{CO}_{2}$. Plant Physiology, v.89, p.952-957, 1989. DOI: 10.1104/PP.89.3.952.

JOHANSEN, D.A. Plant microtechnique. New York: McGraw-Hill, 1940.

KORNDÖRFER, G.H.; PEREIRA, H.S.; NOLLA, A. Análise de silício: solo, planta e fertilizante. 2.ed. Uberlândia: Instituto de Ciências Agrárias, Universidade Federal de Uberlândia, 2004. (Boletim técnico, 2).

KRASENSKY, J.; JONAK, C. Drought, salt, and temperature stress-induced metabolic rearrangements and regulatory networks. Journal of Experimental Botany, v.63, p.1593-1608, 2012. DOI: 10.1093/jxb/err460.

LICHTENTHALER, H.K.; WELBURN, A.R. Determinations of total carotenoids and chlorophylls $a$ and $b$ of leaf extracts in different solvents. Biochemical Society Transactions, v.11, p.591-592, 1983. DOI: 10.1042/bst0110591.

LUZ, B.R. da. Attenuated total reflectance spectroscopy of plant leaves: a tool for ecological and botanical studies. New Phytologist, v.172, p.305-318, 2006. DOI: 10.1111/j.1469-8137.2006.01823.x.

MA, J.F.; MIYAKE, Y.; TAKAHASHI, E. Silicon as a beneficial element for crop plants. In: DATNOFF, L.E.; SNYDER, G.H.; KORNDÖRFER, G.H. (Ed.). Silicon in agriculture. New York: Elsevier, 2001. p.17-39. (Studies in plant science, 8).

MA, J.F.; YAMAJI, N. Silicon uptake and accumulation in higher plants. Trends in Plant Science, v.11, p.392-397, 2006. DOI: 10.1016/j.tplants.2006.06.007.

MEHTA, P.; JAJOO, A.; MATHUR, S.; BHARTI, S. Chlorophyll $a$ fluorescence study revealing effects of high salt stress on Photosystem 
II in wheat leaves. Plant Physiology and Biochemistry, v.48, p.16-20, 2010. DOI: 10.1016/j.plaphy.2009.10.006.

MING, D.F.; PEI, Z.F.; NAEEM, M.S.; GONG, H.J.; ZHOU, W.J. Silicon alleviates PEG-induced water-deficit stresses in upland rice seedlings by enhancing osmotic adjustment. Journal of Agronomy and Crop Science, v.198, p.14-26, 2012. DOI: 10.1111/j.1439-037X.2011.00486.x.

NADEAU, J.A.; SACK, F.D. Stomatal development in Arabidopsis. The Arabidopsis Book, v.1, p.1-26, 2002. DOI: 10.1199/tab.0066.

NAKANO, Y; ASADA, K. Hydrogen peroxide is scavenged by ascorbate-specific peroxidase in spinach chloroplast. Plant and Cell Physiology, v.22, p.867-880, 1981.

O'BRIEN, T.P.; FEDER, N.; MCCULLY, M.E. Polychromatic staining of plant cell walls by toluidine blue O. Protoplasma, v.59, p.368-373, 1964. DOI: 10.1007/BF01248568.

REDDY, A.R.; CHAITANYA, K.V.; VIVEKANANDAN, M. Drought-induced responses of photosynthesis and antioxidant metabolism in higher plants. Journal of Plant Physiology, v.161, p.1189-1202, 2004. DOI: 10.1016/j.jplph.2004.01.013.

SHEN, X.; ZHOU, Y.; DUAN, L.; LI, Z.; ENEJI, A.E.; LI, J. Silicon effects on photosynthesis and antioxidant parameters of soybean seedlings under drought and ultraviolet-B radiation. Journal of Plant Physiology, v.167, p.1248-1252, 2010. DOI: 10.1016/j.jplph.2010.04.011.

SINGH, S.K.; REDDY, K.R. Regulation of photosynthesis, fluorescence, stomatal conductance and water-use efficiency of cowpea (Vigna unguiculata [L.] Walp.) under drought. Journal of Photochemistry and Photobiology B: Biology, v.105, p.40-50, 2011. DOI: 10.1016/j.jphotobiol.2011.07.001.

SINGLETON, V.L.; ROSSI JR., J.A. Colorimetry of total phenolics with phosphomolybdic-phosphotungstic acid reagents. American Journal of Enology and Viticulture, v.16, p.144-158, 1965.

SOUZA, V.C.; LORENZI, H. Botânica sistemática: guia ilustrado para identificação das famílias de Angiospermas da flora brasileira, baseado em APG II. Nova Odessa: Instituto Plantarum, 2005. 640p.

STOCKER, T.F.; QIN, D.; PLATTNER, G.-K.; TIGNOR, M.M.B.; ALLEN, S.K.; BOSCHUNG, J.; NAUELS, A.; XIA, Y.; BEX, V.; MIDGLEY, P.M. (Ed.). Climate change 2013: the physical science basis: working group I contribution to the Fifth Assessment Report of the Intergovernmental Panel on Climate Change. Cambridge: Cambridge University Press, 2013. 1535p. IPCC.

STRASSER, R.J.; TSIMILLI-MICHAEL, M.; SRIVASTAVA, A. Analysis of the fluorescence transient. In: PAPAGEORGIOU, G.C.; GOVINDJEE (Ed.). Chlorophyll fluorescence: a signature of photosynthesis. Dordrecht: Springer, 2004. p.321-362. (Advances in photosynthesis and respiration, 19).

TRENHOLM, L.E.; DATNOFF, L.E.; NAGATA, R.T. Influence of silicon on drought and shade tolerance of st. augustinegrass. HortTechnology, v.14, p.487-90, 2004.

XU, C.; XU, X. Effects of silicon on chlorophyll fluorescence and gas exchange of Zizyphus jujuba cv. Jinsi-xiaozao under salt stress. Journal of Nanjing Medical University, v.29, p.25-28, 2005.

$\overline{\text { Received on May 12, } 2015 \text { and accepted on February 5, } 2016}$ 